DOI https://doi.org/10.30525/978-9934-26-085-8-2

\title{
METHODS OF PRIMARY DIGITAL PROCESSING OF RADIO SIGNALS
}

\section{Bortnyk G. G., Kyrylyuk S. O.}

\section{INTRODUCTION}

Methods of primary processing of radio signals (RS) are widely used in radar, in radio monitoring, in telecommunication systems ${ }^{1}$. The list of tasks that can be solved using the methods of primary processing of the RC includes: analog-to-digital conversion of high-frequency signals, memorization and reproduction of RS, spectral evaluation of RS parameters.

Existing methods of digital processing of RS (DPRS) allow to solve a large number of applications in telecommunications and radio engineering, which previously used analog processing methods. The advantages of DPRS are due to a number of factors. Analog means of RS processing in comparison with digital are characterized by low accuracy and small volume of the processed data. At the same time, the means of digital processing of RS are characterized by the absence of the influence of external destabilizing factors. Using the methods of DPRS, you can create tools that allow you to perform any transformation of the RS by a complex algorithm with a given degree of accuracy ${ }^{2}$.

Currently, a large number of papers have been published that address various theoretical and practical issues related to DPRS ${ }^{3}$. Analysis of publications on the application of DPRS methods for primary treatment of RS suggests that they consider the synthesis of optimal for the selected criteria of their individual elements. However, there is a class of scientific and technical problems in solving which the use of classical methods of DPRS is ineffective due to uncertainty of the value of the carrier frequency, type of modulation, manipulation rate, type of demodulated signal.

1 Рембовский А.М., Ашихмин А.В., Козьмин В.А. Радиомониторинг задачи, методы средства. Москва, 2010. 624 с.

2 Бортник Г.Г., Кичак В.М. Методи та засоби обробки високочастотних сигналів : монографія. Вінниц я: Універсум-Вінниця, 1998. 132 с.

3 Айфичер Э., Джервис У. Цифровая обработка сигналов: практический подход / пер. с англ. Москва, 2004. 992 с. 
The real characteristics of the means of primary digital processing of RS do not reach their potential limits, due to the limited dynamic range of analog-to-digital converters of RS and low productivity of DPRS processes. A number of methods for rapid determination of discrete Fourier transform (DFT) are proposed, which allow to reduce the amount of calculations compared to the direct implementation of $\mathrm{DFT}^{4}$. However, as studies have shown, there is a reserve to improve the productivity of primary treatment of $\mathrm{RS}^{5}$. Analysis of recent publications shows that despite the large number of existing methods of primary digital processing of RS, the development of new methods of wide-range analog-to-digital conversion of RS and high-performance methods of digital spectral evaluation of RS continues now and can not be considered complete.

\section{Method of expanding dynamic range of analog-to-digital converters of means of primary digital processing of RS}

Analog-to-digital converter (ADC) is one of the most important components of modern and promising means of primary processing of RS. ADC largely determine their marginal capabilities in both speed and dynamic range. Therefore, the developers of digital primary processing tools focus on expanding the dynamic range of ADC. However, the use of known methods and approaches in improving the characteristics of the $\mathrm{ADC}$ for the conversion of RS do not allow to implement a potentially achievable dynamic range ${ }^{6}$. This is explained by the fact that the real means of analog-to-digital conversion of RS introduce significant distortions in the digital representation of signals in the form of parasitic frequency components, due to the nonlinearity of the functional nodes of the ADC. The parasitic components of the spectrum that occur in the output signal of the ADC, lead to a limitation of the dynamic range of the converter and, accordingly, the means of primary processing of the RS.

Thus, the urgent task is to develop an ADC with an extended dynamic range while maintaining the potentially high speed of the primary processing of the RS.

4 Кестер У. Проектирование систем цифровой и смешанной обработки сигналов / пер. с англ. Москва, 2010. 328 с.

5 Лайонс Р. Цифровая обработка сигналов / пер. с англ. Москва, 2006. 656 с.

6 Бортник Г.Г., Бортник С.Г., Кичак В.М. Методи та засоби аналогоцифрового перетворення високочастотних сигналів: монографія. Вінниця : ВНТУ, 2014. 128 c. 
Expansion of the dynamic range of the ADC of digital RS processing is possible due to digital filtering of the output signals of the analog-todigital converter.

By processing the RS in the ideal analog part of the ADC, which does not make its own noise and distortion, you can change the dynamic range due to bandpass filtering. This procedure is used to meet the requirements of the sample theorem when discretizing the RS using an ADC. Band filtering should be performed in the absence of significant distortion of the processed RS. It should be noted that the bandwidth of this filter $\Delta f_{b f}$ may be narrower than the frequency band of the input RS $\Delta f_{\text {in }}$. Under such conditions, the noise dispersion is proportional to the ADC bandwidth. The filtering factor for the ideal analog part of the ADC is defined as

$$
Q_{i a p}=10 \log \frac{\Delta f_{i n}}{\Delta f_{b f}} .
$$

Expression (1) shows the gain in the dynamic range for the analog part of the ADC, which does not introduce its own noise and distortion. Real nodes are characterized by losses $\alpha_{a}$ due to the addition of intrinsic noise of analog components of the ADC. The expression for the filtration coefficient of the real analog part of the ADC is as follows:

$$
Q_{i a p}=10 \log \frac{\Delta f_{i n}}{\Delta f_{b f}}-\alpha_{a} .
$$

The filtering factor of the digital part of the ADC depends on the spectral composition of the output signal of the converter. The complexity of the analysis of the passage of the RS circuits of the analog-to-digital converter is that the $\mathrm{ADC}$ is an inertial nonlinear device and therefore the complete model must take into account both features and is complex. A simpler model is to analyze the ADC as an inertial device, which is possible for RS with frequencies that are lower than the maximum frequencies of the ADC. If RS whose level may exceed the dynamic range of the ADC are processed, then its model should take into account the effect of limiting the input signal. For radio signals whose level does not reach the limit of the dynamic range of the ADC, its model may not take into account the constraint processes and thus is a simpler model of the ADC. The analysis of such a model is expedient because it allows to obtain the limit values of the characteristic for a given nonlinear transformation.

Let's analyze the effect of the quantization procedure on the spectrum of radio signals. For the case of an ideal inertial ADC, its output signal can be represented as the sum of two characteristics 


$$
U_{\text {out }}=U_{l}\left[U_{i n}\right]+U_{n l}\left[U_{i n}\right] \text {, }
$$

where $U_{l}\left[U_{i n}\right]$ - the linear amplitude characteristic of the ADC, which corresponds to the undistorted processing of radio signals;

$U_{n l}\left[U_{i n}\right]$ - nonlinear amplitude characteristic of the ADC.

The nonlinear characteristic of ACT is a periodic function of the input noise process with a period equal to the quantization step $h$, that is

$$
U_{n l}\left[U_{i n}\right]=U_{n l}\left[U_{i n}+i \cdot h\right] \text {, }
$$

where $i= \pm 1, \pm 2, \ldots$

A generalized model of the analog-to-digital conversion process based on expression (3) is shown in fig. 1.

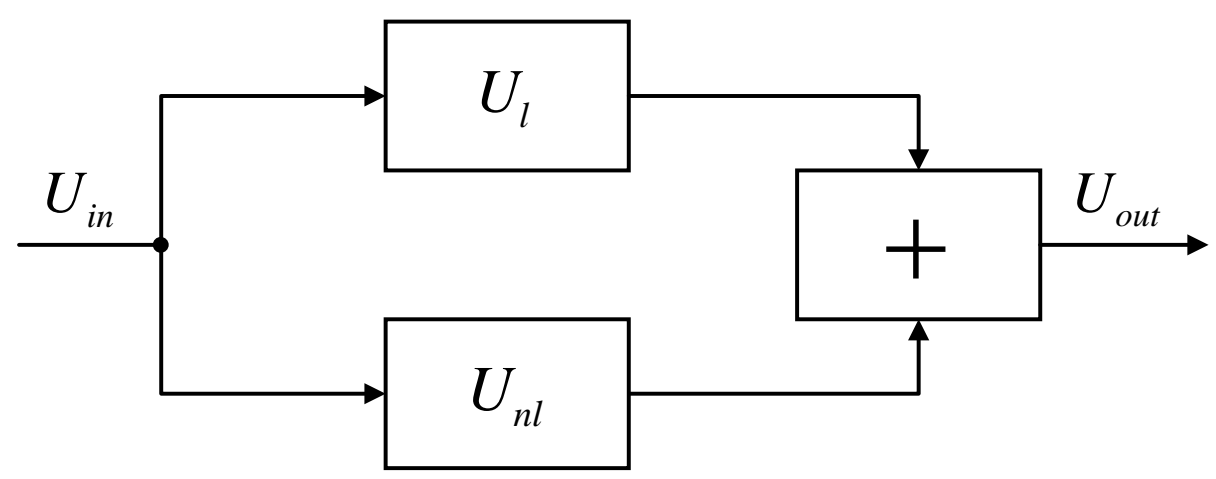

Fig. 1. Generalized model of the analog-digital process transformation

The presence of nonlinear distortions in the ADC according to fig. 1 is a circle with a characteristic $U_{n l}\left[U_{i n}\right]$.

In fig. 2 shows the amplitude characteristic of the ADC and the characteristics of the nonlinear component of the converter. In this case $U_{n l}\left[U_{i n}\right]$ it is a periodic function with a period $h$ characterized by a constant component $0,5 \cdot h$. This function decomposes into a Fourier series. Therefore, the nonlinear distortions that occur in the ADC can be represented by a Fourier series ${ }^{7}$.

$$
U_{n l}\left[U_{i n}\right]=\sum_{k=1}^{\infty} a_{k} \sin \left[\frac{2 \pi k U_{i n}}{h}\right] .
$$

7 Бортник Г.Г., Бортник С.Г. Дослідження інтегральної нелінійності аналого-цифрового перетворювача у базисі дискретних функцій Фур'є. Вісник Віннищького політехнічного інституту. 2005. № 5. С. 117-119. 

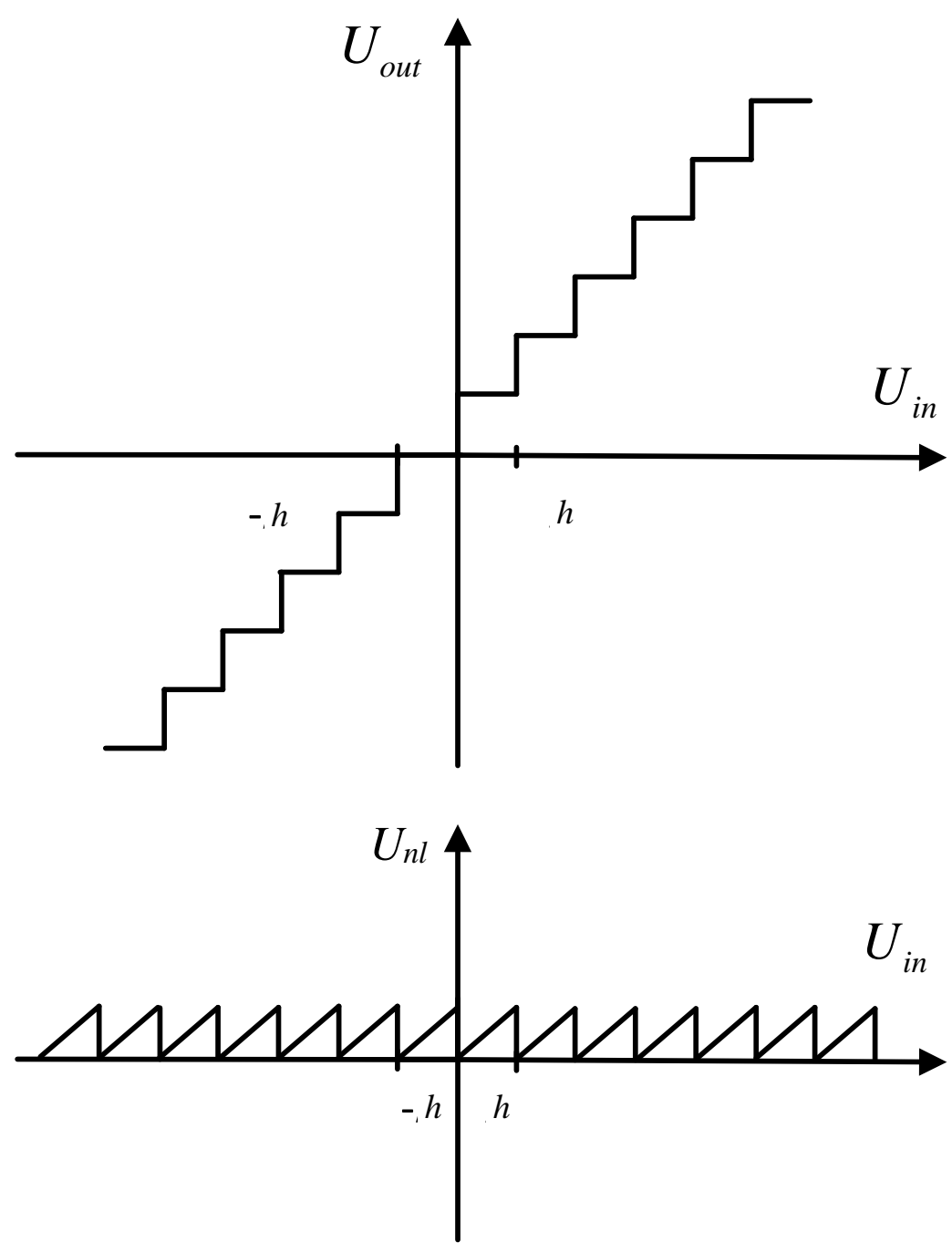

Fig. 2. Amplitude characteristics of the ADC and its nonlinear part

The Fourier series coefficients can be found as

$$
a_{k}=\frac{1}{h} \int_{-0,5 h}^{0,5 h} U_{n l} \sin \left[\frac{2 \pi k U_{i n}}{h}\right] d U_{i n}=\frac{h \cdot \cos (\pi k)}{\pi k} .
$$

The nonlinear characteristic of the ADC taking into account expression (6) will take the following form

$$
U_{n l}\left[U_{i n}\right]=\sum_{k=1}^{\infty} \frac{h \cdot \cos (\pi k)}{\pi k} \sin \left[\frac{2 \pi k U_{i n}}{h}\right] .
$$

Let us analyze the process of passing a sinusoidal signal through the analog-to-digital conversion path in order to estimate nonlinear distortions in the ADC. The ADC input signal has the form 


$$
U_{\text {in }}[t]=U_{m} \cos (\omega t) \text {. }
$$

Substitute (8) into expression (7) and as a result we obtain the expression for the original components of the ADC due to nonlinear distortions:

$$
\begin{gathered}
U_{n l}[t]=h \sum_{k=1}^{\infty} \frac{\cos (\pi k)}{\pi k} \sin \left[\frac{2 \pi k U_{m}}{h} \cos (\omega t)\right]= \\
=h \sum_{k=1}^{\infty} \frac{\cos (\pi k)}{\pi k} 2 \sum_{m=0}^{\infty}(-1)^{m} J_{2 m+1}\left[\frac{2 \pi k U_{m}}{h}\right] \cdot \cos [(2 m+1) \omega t],
\end{gathered}
$$

where $J_{p}(x)$ - Bessel function of the first kind of order $p$.

Therefore, when a sinusoidal signal is applied to the ADC input, odd components of the input signal $(\omega, 3 \omega \ldots)$ are formed as a result of nonlinear distortions in its output signal. Therefore, it is advisable to perform digital filtering of the ADC output signal in order to suppress the parasitic high-frequency harmonics of the signal.

The expression for estimating the filtration coefficient of the digital part of the ADC has the form similar to expression (1):

$$
Q_{i d p}=10 \log \frac{\Delta f_{b f}}{\Delta f_{\text {out }}} .
$$

This expression is valid only for the ideal implementation of a digital radio signal filter in an ADC. In practice, $\mathrm{ADCs}$ make some losses $\alpha_{d}$ in digital signal processing. Therefore, expression (10) will take the following form

$$
Q_{r d p}=10 \log \frac{\Delta f_{b f}}{\Delta f_{\text {out }}}-\alpha_{d} .
$$

The presence of losses $\alpha_{d}$ is due to "window weighing" (and the specific values of losses depend on the type of window function used, for example, for the Hamming function $\alpha_{d}=1,34 d B$ ).

The block diagram of the device of analog-to-digital conversion of radio signals, operating on the basis of the proposed method, is shown in fig. 3.

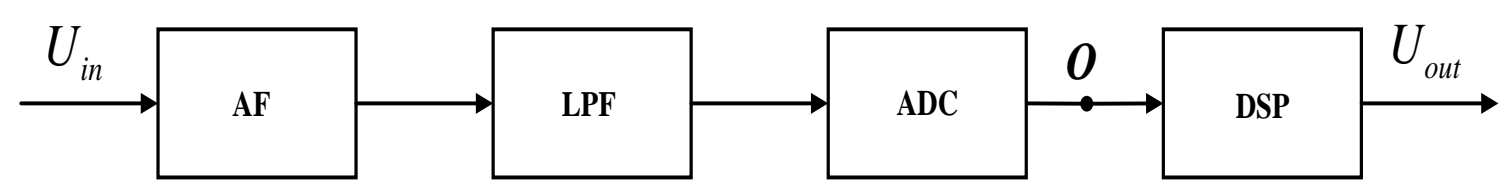




\section{Fig. 3. Block diagram of the analog-digital device conversion of radio signals based on digital filtering of the ADC output signal}

The analog part of the device contains the amplification units (AF) and the low-pass filter (LPF) connected in series. The output signal of the analog-to-digital conversion device is processed by a digital signal processor (DSP) according to the digital filtering algorithm.

Let's analyze the effectiveness of the proposed method. To do this, when evaluating the effectiveness of the method, it should be assumed that the dynamic range of the input analog part of the analog-to-digital conversion device is wider than the dynamic range of the ADC. The dynamic range of the ADC in a given frequency band is equal to the value declared in the passport characteristics $D_{A D C}$. In the frequency band $\Delta f_{b f}$, the dynamic range of the ADC, taking into account the filtering factor in the analog part of the device of analog-to-digital conversion is equal to:

$$
D_{A D T_{a f}}=D_{A D C}+10 \lg \frac{\Delta f_{i n}}{\Delta f_{b f}}-\alpha_{a} .
$$

We use the expression for the dynamic range of the device of analogto-digital conversion, taking into account the features of the mode of sampling of radio signals ${ }^{8}$

$$
D_{A D T_{d}}=D_{A D C}+10 \lg \frac{f_{s}}{2 \Delta f_{b f}},
$$

where $f_{s}-$ ADC sampling frequency.

For the case when the root mean square value of the natural noise of the analog part of the device of analog-to-digital conversion exceeds the root mean square value of the ADC noise $\sqrt{c^{2}+1}$ times, the dynamic range of the device at point $\mathrm{O}$ is equal to'

$$
D_{A D T_{O}}=D_{A D C}+10 \lg \frac{f_{s}}{2\left(c^{2}+1\right) \Delta f_{b f}} .
$$

${ }^{8}$ Бортник Г.Г., Васильківський М.В., Стальченко О.В. Пристрій аналогоцифрового перетворення високочастотних сигналів. Вимірювальна та обчислювальна техніка в технологічних процесах. 2013. № 2. С. 82-85.

${ }^{9}$ Бортник Г.Г., Мінов М.Л., Стальченко О.В. Аналіз ефективності аналогоцифрового перетворення сигналів у радіотехнічних комплексах. Інформаційні технологї та комп ’ютерна інженерія. 2011. № 2. С. 12-15. 
The dynamic range at the output of the analog-to-digital conversion device is wider than the dynamic range at point $\mathrm{O}$ by the value of the filtering factor of the digital part:

$$
D_{A D T_{d f}}=D_{A D C}+10 \lg \frac{f_{s}}{2\left(c^{2}+1\right) \Delta f_{\text {out }}}-\alpha_{d} .
$$

In fig. 4 shows the dependences of the dynamic range of the analog-todigital conversion device, built on the basis of a 12-bit ADC, on the normalized sampling frequency of the frequency band of radio signals for different cases of filtering.

Curve 1 characterizes the case of digital filtering of the PC using Hamming weight functions, and curve 2 - using the Kaiser-Bessel weight functions. The lower curve 3 corresponds to an analog-to-digital conversion device with analog bandpass filtering of radio signals. As can be seen from the graphs, the dynamic range of the analog-to-digital conversion device decreases with increasing frequency of the input RS. In this case, digital filtering based on the weighting function of Hamming provides higher values of the dynamic range $(82 \div 78 \mathrm{~dB}$ depending on the frequency of the input signal). At the same time, analog filtering provides a dynamic range of analog-to-digital conversion device in the range of $76 \div 71 \mathrm{~dB}$.

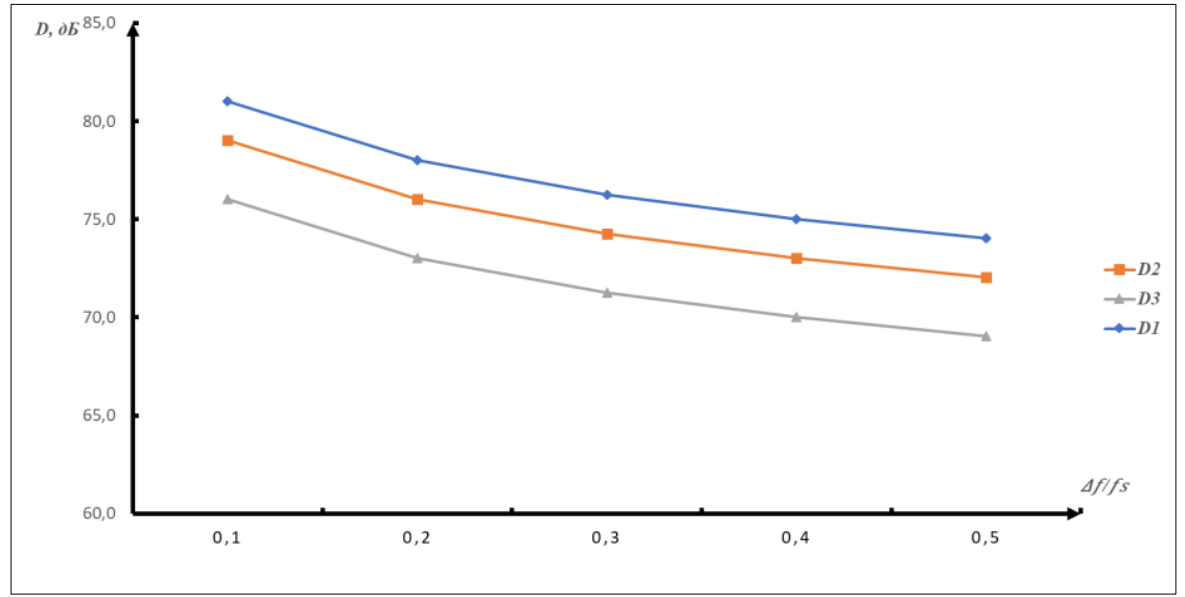

\section{Fig. 4. Dependence of the dynamic range of the analog-to-digital conversion device on the frequency band of the input $R S$}

Thus, the proposed method makes it possible to significantly expand the dynamic range of digital $\mathrm{RS}$ processing devices and ensure the functioning of radio and telecommunications systems with a wide class of signals. 


\section{Method of memorization and reproduction of radio signals}

Means of memorization and reproduction of radio signals are an integral part of radio and telecommunication systems. They are designed to remember the frequency-time structure of the analyzed RS, output data to the means of monitoring these signals and playback of processed radio signals.

It is proposed to increase the productivity of digital means of memory and reproduction of the RS by reducing the computational complexity of the procedures of the DPRS.

Modern digital RS primary processing devices use three methods of storing and reproducing radio signals. According to the first method, the sequence of time-discretized and quantized by the level of instantaneous readings of radio signals is stored. The digital equivalent of the PC is stored and then restored using a digital-to-analog converter (DAC). This method is characterized by narrow functionality and low productivity of radio signal processing.

The second method is amplitude-phase. It provides a digital representation of the amplitude (envelope) and phase of radio signals. The amplitude and phase readings are stored in random access memory (RAM). Restoration of the analog form of a signal occurs by means of amplitude and phase modulation of a high-frequency carrier signal of the generator. The characteristics of the amplitude and phase modulation are set according to the digital codes of the amplitude and phase, which are read from the RAM. This method is characterized by a number of disadvantages, namely: high hardware costs, low accuracy of reproduction of the RS and low performance of the means of reproduction of radio signals.

The third spectral method uses the representation of radio signals $x(t)$ in spectral form $S(\omega)$ with its subsequent digital processing. At the same time fast algorithms of DFT are used. Unlike previous methods, the spectral method involves recording in the RAM of digital samples of the spectrum of the radio signal $S(k)$, and the recovery of the analog radio signal is carried out using the inverse DFT (IDFT). It is obvious that the spectral method provides DPRS mainly in the frequency domain.

The advantages of spectral digital processing of radio signals are the possibility of operative analysis of spectra of radio signals, wide possibilities of synthesis of digital signals by means of algorithms of fast digital convolution, considerable reduction of number of operations at digital filtering. Therefore, it is advisable to use the spectral methodology 
of signal processing in the construction of means of primary processing of radio signals.

The structure of the processes of conversion and processing of radio signals based on the spectral method is shown in fig. 5 .

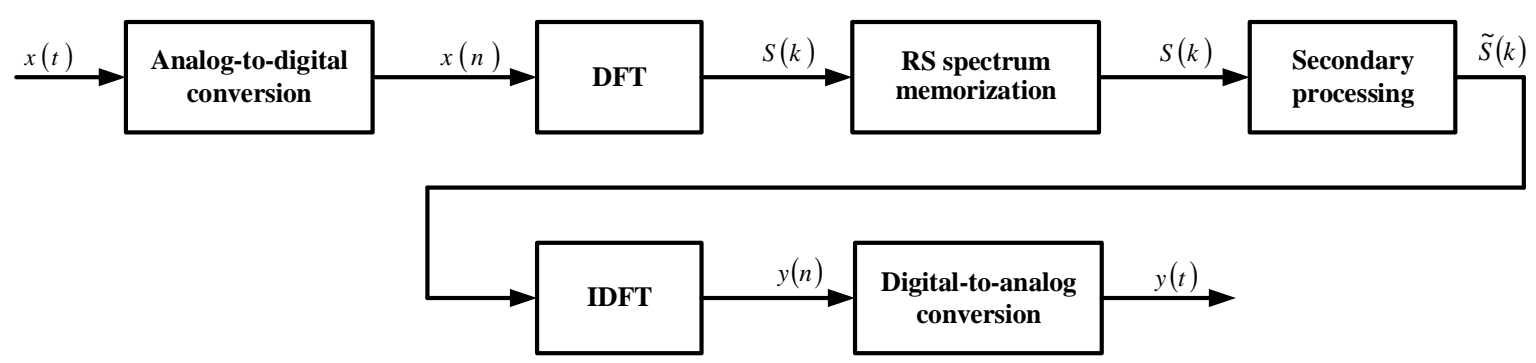

Fig. 5. The structure of the processes of conversion and processing of radio signals

The input RS $x(t)$ must be converted to digital code $x(n)$. In the future, with the help of DFT methods, the transfer of RS $x(n)$ from the time to the frequency domain is performed $S(k)$. The received readings of the RS in the frequency domain $S(k)$ are stored in the RAM. The next step is the secondary processing of RS in the frequency domain, such as digital filtering or digital convolution. Next, the transfer of radio signals from the spectral to the time domain $y(n)$ using IDFT methods. The last stage is the digital-to-analog conversion into a continuous form $y(t)$.

The stage of transferring a digital radio signal from the time to the frequency domain takes the longest period of time when processing the RS. Therefore, increasing the productivity of this processing is an important step in the development of means of primary processing of RS. DFT and fast algorithms for its implementation assume that the input sequence is complex. At the same time, a real digital RS is formed at the ADC output. The use of complex FFT algorithms to the actual signal leads, on the one hand, to large computational costs, and on the other - to the excess amount of RAM.

There are a number of FFT algorithms for valid sequences ${ }^{10}$. These algorithms are characterized by irregular structure and small values of the coefficient of productivity. Therefore, there is a need to develop a method for rapid transfer of RS in the spectral region, which is specially adapted for the case of real RS at the output of the ADC.

10 Смит С. Цифровая обработка сигналов. Практическое руководство для инженеров и научных работников. Москва, 2008. 720 с. 
Let the sequence $x(n)$ be represented as two subsequences: $x_{1}(n)$ and $x_{2}(n)$. Each of these subsequences is characterized by length $0,5 \cdot N$. These subsequences are formed from even and odd samples of the ADC source code:

$$
\begin{aligned}
& x_{1}(n)=x(2 n) ; \\
& x_{2}(n)=x(2 n+1),
\end{aligned}
$$

where $n=0,1, \ldots, 0,5 \cdot N-1$.

Then the DFT of the output digital signal of the ADC $x(n)$ sample $N$ volume, can be represented as follows

$$
S(k)=\sum_{n=0}^{0,5 \cdot N-1} x(2 n) \cdot e^{-j \frac{2 \pi}{N} \cdot 2 \cdot n k}+\sum_{n=0}^{0,5 \cdot N-1} x(2 n+1) \cdot e^{-j \frac{2 \pi}{N} \cdot(2 n-1) k} .
$$

Taking into account expression (16) for even and odd ADC readings, expression (17) will take the following form

$$
S(k)=\sum_{n=0}^{0,5 \cdot N-1} x_{1}(n) \cdot e^{-j \frac{2 \pi}{0,5 \cdot N} \cdot n k}+\left[\sum_{n=0}^{0,5 \cdot N-1} x_{2}(n) \cdot e^{-j \frac{2 \pi}{0,5 \cdot N} \cdot n k}\right] \cdot e^{-j \frac{2 \pi}{N} \cdot k} .
$$

Then

$$
S(k)=S_{1}(k)+S_{2}(k) \cdot e^{-j \frac{2 \pi}{N} \cdot k},
$$

then $S_{1}(k), S_{2}(k),-$ coefficients $0,5 \cdot N$ - point DFT subsequences $x_{1}(n)$ and $x_{2}(n)$.

The last expression shows how the $N$-point DFT of the digital ADC signal is connected with two $0,5 \cdot N$-point DFT even and odd samples of the same ADC output signal.

It is known that the ADC output signal is valid. Therefore, the subsequences $x_{1}(n)$ and $x_{2}(n)$ are also valid. We carry out formation of a new complex sequence by volume of $0,5 \cdot N$ samples on the basis of two valid subsequences:

$$
y(n)=x_{1}(n)+j \cdot x_{2}(n),
$$

where $n=0,1,2 \ldots, 0,5 \cdot N-1$.

DFT sequence $y(n)$ is defined as

$$
y(k)=\sum_{n=0}^{0,5 \cdot N-1}\left[x_{1}(n)+j \cdot x_{2}(n)\right] \cdot e^{-j \frac{2 \pi}{0,5 \cdot N} \cdot n k},
$$

where $k=0,1,2 \ldots, 0,5 \cdot N-1$. 
Due to the property of symmetry of the spectra of real sequences, by using a single FFT, can be obtained

$$
\begin{aligned}
& S_{1}(k)=\frac{y(k)+y^{*}(N-k)}{2} ; \\
& S_{2}(k)=\frac{y(k)+y^{*}(N-k)}{2 \cdot j},
\end{aligned}
$$

where $y^{*}(N-k)$ - complex-conjugate value of DFT sequence $y(n)$ at a point $(N-k)$.

Taking into account expression (19) we obtain the formula for finding $N$-point DFT real digital ADC signal $x(n)$ using FFT volume $0,5 \cdot N$ :

$$
S(k)=\frac{y(k)+y^{*}(N-k)}{2}+\frac{y(k)-y^{*}(N-k)}{2 \cdot j} \cdot e^{-j \frac{2 \pi}{N} \cdot k},
$$

where $k=0,1,2 \ldots, 0,5 \cdot N-1$.

Values $S(k)$ for $k=0,5 \cdot N, \ldots, N-1$ are based on the properties of symmetry of the spectra of real signals.

Thus, finding the spectrum of the ADC output signal involves three successive stages of processing digital samples from the ADC output. The first stage involves the preliminary processing of the signal - the formation of a complex $0,5 \cdot N$-point sequence from even and odd samples of the output signal of the ADC. In the second stage, a rapid DFT complex sequence volume is carried out $0,5 \cdot N$. At the final stage of processing according to expression (23) it is necessary to perform one complex multiplication and three complex additions to determine one sample in the spectral region.

To transfer the RS to the time domain according to its known components in the frequency domain, the inverse DFT is performed. In order to increase the productivity of this process, it is proposed to perform IDFT based on the method of direct FFT (as in finding the spectra of signals). It is known that IDFT is according to the expression ${ }^{11}$ :

$$
x(n)=\frac{1}{N} \sum_{k=0}^{N-1} S(k) \cdot e^{j \frac{2 \pi}{N} \cdot n \cdot k} .
$$

11 Ахмед Н., Рао К.Р. Ортогональные преобразования при обработке цифровых сигналов / пер. с англ. Москва, 1980. 248 с. 
The complex-conjugate sequence $x(n)^{*}$ of the signal in the time domain with respect to the multiplier $N$ can be found using the expression for DFT to the sequence $S^{*}(k)$ :

$$
N \cdot x^{*}(n)=\sum_{k=0}^{N-1} S^{*}(k) \cdot e^{-j \frac{2 \pi}{N} \cdot n \cdot k} .
$$

You can then find the IDFT from the spectral components of the RS by the operation of complex conjugation and adjusting the expression to the value $N$ :

$$
x(n)=\frac{1}{N}\left[\sum_{k=0}^{N-1} S^{*}(k) \cdot e^{-j \frac{2 \pi}{N} \cdot n \cdot k}\right]^{*} .
$$

Therefore, the reproduction of RS in the time domain using IDFT and direct FFT algorithm is performed in three stages. The first stage involves the formation of a sequence $S(k)$ of complex-conjugate sequence $S^{*}(k)$. During the second stage, it is determined $x^{*}(n)$ using the FFT taking into account the multiplier $1 / N$. At the last stage is the original sequence of the signal $x(n)$ in the time domain from the complex-conjugate sequence $x^{*}(n)$.

Analog-to-digital conversion and finding the spectrum of the RS is carried out in real time without loss of information. Subsequent secondary signal processing is performed with a performance that depends on the element base of the selected device ${ }^{12}$. The block diagram of the block of primary processing of RS, implementing the proposed method, is shown in fig. 6 .

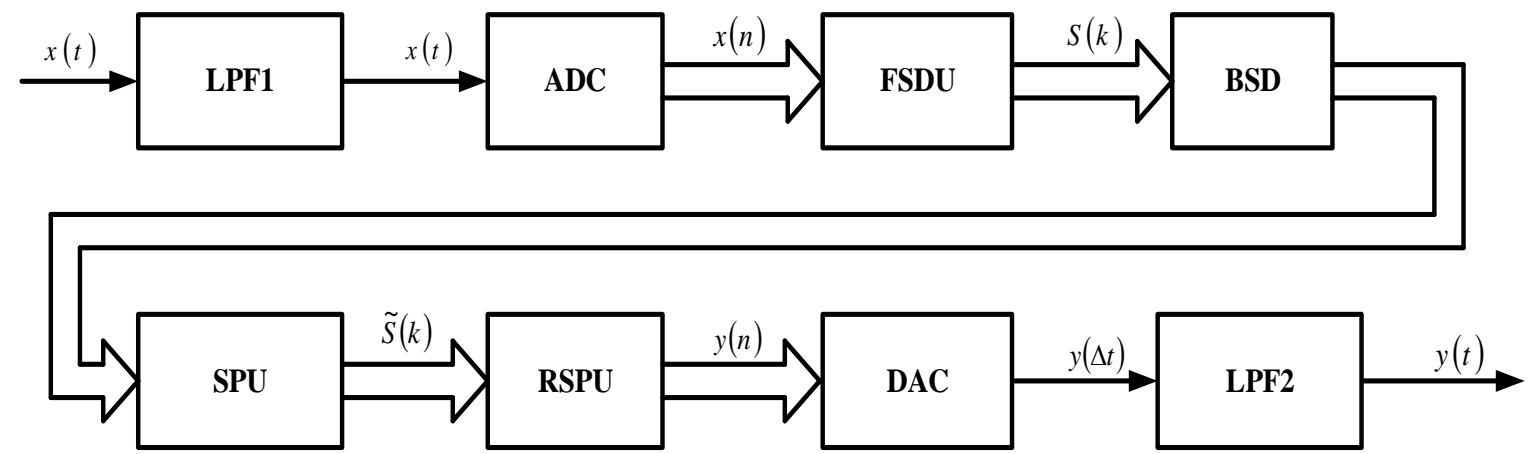

Fig. 6. Block diagram of the primary processing unit of the RS

12 Бортник Г.Г. Швидкодіючий аналого-цифровий перетворювач підвищеної точності. Вісник Вінницького політехнічного інституту. 2002. № 5. С. 47-50. 
The radio signal $x(t)$ passes through a low-pass filter (LPF1), which attenuates the effect of overlapping spectra and is fed to the ADC input. At the output of the ADC, the digital equivalent of the radio signal $x(n)$ is generated, which arrives at the fast spectrum detection unit (FSDU), which contains the frequency samples of the RS $S(k)$. The readings are stored in the buffer storage device (BSD).

Subsequently, the processing of the RS in the frequency domain is performed in the secondary processing unit (SPU). At the output of the SPU frequency samples $\tilde{S}(k)$ are formed, which are fed to the input of the RS playback unit (RSPU), where it is transferred to the time domain. Using the DAC is the conversion of a digital signal $y(n)$ into an amplitude-pulse-modulated (APM) signal $y(\Delta t)$. LPF2 performs the functions of APM demodulator. A continuous signal is generated at its output $y(t)$.

Let's analyze the performance of the proposed method, which is convenient to estimate by the number of multiplication operations. A generalization of this criterion is the coefficient of productivity, which shows the gain among the required "long" multiplication operations, when applying the proposed methods of processing RS in relation to processing methods based on classical FFT and IDFT $^{13}$ :

$$
G_{S}=\frac{C_{F F T}}{C_{D S A}}
$$

where $C_{F F T}$ - the number of "long" multiplication operations in the direct analysis of the RS spectrum based on FFT;

$C_{D S A}$ - the number of multiplication operations using the proposed methods.

Spectral analysis of RS based on the direct execution of FFT requires $0,5 \cdot N \cdot \log _{2} N$ multiplication operations, and to recover the signal in the time domain based on the traditional fast IDFT algorithm requires $2 \cdot N \cdot \log _{2} N$ multiplication.

The implementation of these RS processing procedures according to the proposed methods requires the performance of $0,25 \cdot N \cdot \log _{2}(0,5 \cdot N)+N$ multiplication operations for spectral analysis and

13 Бортник Г.Г., Васильківський М.В., Стальченко О.В. Цифровий метод спектрального оцінювання випадкових сигналів. Вісник Вінницького політехнічного інституту. 2014. № 2. С. 108-114. 
$N \cdot \log _{2} N$ multiplication operations for time recovery of RS, respectively. Hence the performance ratio can be found as

$$
G_{S}=\frac{2,5 \cdot N \cdot \log _{2} N}{0,25 \cdot N \cdot \log _{2}(0,5 \cdot N)+N+N \cdot \log _{2} N} .
$$

Graphs of the dependence of the productivity coefficient on the volume of the analyzed sample of RS are shown in fig. 7.

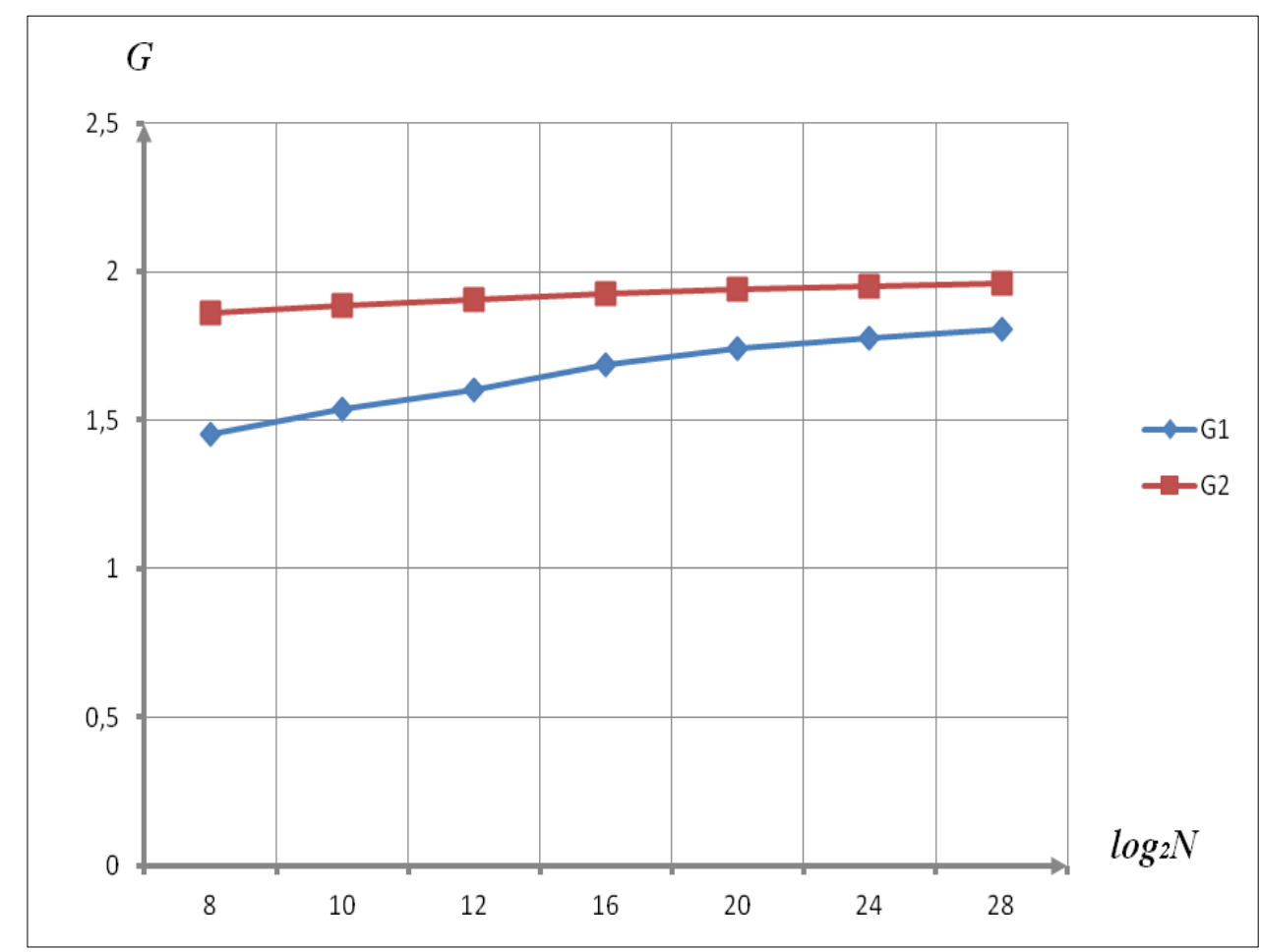

Fig. 7. Dependence of the productivity factor on the sample size of the RS

The proposed methods of transferring the RS from the time domain to the spectral domain and vice versa, based on multi-stage digital processing of samples of the studied RS make it possible to significantly reduce the time to find the spectral and temporal components of the signal and ensure the mode of primary DPRS.

\section{Digital method of spectral analysis broadband radio signals}

Existing devices for spectral analysis of broadband RS are based on the use of digital signal processing (DSP) methods, namely FFT algorithms. Spectral analysis of broadband RS based on FFT algorithms has features that are associated with the desired resolution in frequency 
and specified processing performance ${ }^{14}$. The direct application of the FFT technique for the implementation of these contradictory requirements is considered a complex scientific and technical task. However, when solving problems related to the spectral analysis of broadband RS in the means of primary processing of radio signals operating in real time, the performance of existing methods and devices of the DSP is insufficient.

In recent years, a number of modified methods of spectral analysis of RS based on DSP algorithms have been proposed, which were developed to reduce the performance constraints inherent in the digital processing methods. In the mode of operation in real time it is necessary to carry out processing of broadband RS at which there are no losses of samples of the analyzed signals and at the same time there is no growing from realization to realization of their unlimited accumulation.

Improving the performance of spectral analysis of broadband RS is proposed by dividing the implementation of RS into a number of subsequences with their subsequent processing in the spectral region.

The criterion for broadband digital spectrum analyzer is the frequency overlap coefficient ${ }^{15}$ :

$$
k_{f}=\frac{f_{H}}{f_{L}},
$$

where $f_{H}, f_{L}$ - upper and lower frequencies of the studied spectrum of RS.

Frequency resolution is estimated by the relative frequency division factor:

$$
\beta=\frac{\Delta f}{f},
$$

where $\Delta f$ - absolute frequency division or frequency interval between adjacent frequency components of the spectrum.

For the FFT-based RS spectral analysis method, the absolute frequency separation is constant over the entire frequency range and is defined as

$$
\Delta f=\frac{f_{S}}{N}
$$

where $f_{S}$ - sampling frequency;

$N$ - the sample size of the studied RS.

14 Радзиевский В.Г., Трифонов П.А. Обработка сверхширокополосных сигналов и помех. Москва, 2009. 288 с.

15 Афонский А.А., Дьяконов В.П. Цифровые анализаторы спектра, сигналов и логики. Москва, 2009. 248 с. 
The maximum value of the relative separation coefficient $\beta_{\max }$ is reached at the frequency $f_{L}$. Taking into account expressions (29) and (31), we can find the marginal coefficient of relative separation:

$$
\beta_{\text {max }}=k_{f} \cdot \beta_{\text {min }} \text {. }
$$

Using the requirements of the reference theorem, we can write:

$$
\begin{gathered}
k_{f} \leq \frac{N}{2} ; \\
\frac{2}{N} \leq \beta \leq 1 .
\end{gathered}
$$

As is known from the theory of spectral analysis of RS, the requirements for providing the necessary $k_{f}$ and $\beta$ are contradictory. Suppose you need to perform spectral analysis of a broadband RS, the frequency spectrum of which takes $n$ decade, and the maximum value of the relative separation coefficient should not exceed the set value $\beta_{0}$. From expression (32) we obtain $k_{f} \cdot \beta_{\text {min }}=k_{f} \frac{f_{S}}{N \cdot f_{H}} \leq \beta_{0}$. It is now possible to estimate the minimum sample size of the RS to achieve a given frequency separation

$$
N_{\min } \geq \frac{k_{f}}{\beta_{0}} \cdot \frac{f_{S}}{f} .
$$

When implementing the digital method of spectral analysis of broadband RS based on FFT, the coefficient of relative separation by frequency is within $0,01 \leq \beta \leq 0,0001^{16}$. Therefore, for $n=5$ for the value of $\beta_{0}=0,001$ we obtain $N_{\text {min }} \geq 2 \cdot 10^{8}$. In the high-frequency range, the coefficient of relative separation $\beta_{\text {min }}=10^{-8}$, which is excessive for spectral analysis of broadband RS.

To eliminate the shortcomings of the traditional method of spectral analysis of RS based on FFT, it is proposed to divide the studied implementation of broadband RS into a number of subsequences. In this case, for each of the subsequences it is necessary to set the FFT parameters.

Let's perform a preliminary estimate of the real value of $k_{r}$ for the implementation of the FFT subsequence of volume $M$. In the

16 Ширман Я.Д. Радиоэлектронные системы: основы построения и теория. Москва, 2007. 512 с. 
high-frequency part of the spectrum of the studied RS, the value of $k_{r}$ is limited by the relative frequency band of the low-pass filter (LPF) $k_{B}=\frac{f_{S}}{f_{H}}$, which weakens the effect of overlapping spectra. Then

$$
f_{S}=k_{B} \cdot f_{H} \cdot
$$

In the low-frequency range of the RS spectrum, the coefficient $k_{B}$ is limited by the allowable value of $\beta_{\max }$

$$
f_{L}=\frac{f_{S}}{N \cdot \beta_{\max }} .
$$

Taking into account expressions (35) and (36) we obtain

$$
k_{r}=\frac{N \cdot \beta_{\max }}{k_{B}} .
$$

Divide the frequency range of a broadband RS into $m$ overlapping subbands with an overlap coefficient $k_{i}=\frac{f_{H_{i}}}{f_{L_{i}}}$. Then for the $i$-subband we get the absolute division by frequency

$$
\Delta f_{i}=\frac{f_{S_{i}}}{M_{i}}=f_{L_{i}} \cdot \beta_{\max _{i}} .
$$

From expression (38) it is seen that at a given value of $\beta_{\max _{i}}$, a decrease in $f_{L_{i}}$ leads to the need to reduce the sampling frequency $f_{S_{i}}$ or a proportional increase in volume $M_{i}$. When moving to the next subband according to expression (38) we obtain: $\Delta f_{i+1}=f_{L_{(i+1)}} \cdot \beta_{\max (i+1)}$.

From here we have:

$$
\frac{\Delta f_{i+1}}{\Delta f_{i}}=\frac{f_{L_{(i+1)}}}{f_{L_{i}}} \cdot \frac{\beta_{\max _{(i+1)}}}{\beta_{\max _{i}}} .
$$

In the case where the individual subbands do not overlap, then $f_{L_{i+1)}}=f_{H_{i}}$. Then from expression (39) we can obtain the relationship between the sampling frequencies of adjacent subbands:

$$
\frac{f_{S_{(i+1)}}}{f_{S_{i}}}=k_{i} \frac{\beta_{\max _{(i+1)}}}{\beta_{\max _{i}}} \cdot \frac{M_{i+1}}{M_{i}} .
$$


Relation (40) makes it possible to estimate the main parameters of the FFT procedure for each subsequence obtained from the array of samples of the studied broadband RS. Therefore, it is possible to formulate the main stages of implementation of the digital method of spectral analysis of broadband RS.

1) First, the value of the total overlap coefficient by frequency $k_{f}$ is set and the initial frequency range is divided into $m$ subbands.

At imposing of the corresponding frequency zones we will receive:

$$
k_{f}=\prod_{i=1}^{m} k_{f_{i}} .
$$

2) The length of the processed subsequence is calculated taking into account the limit value of the relative separation coefficient by frequency $\beta_{\max _{i}}$ and the relative frequency band of the LPF $k_{B_{i}}$

$$
M_{i}=\frac{k_{B_{i}} \cdot k_{f_{i}}}{\beta_{\max _{i}}} .
$$

3) According to the known values of $k_{B_{n}}$ and $f_{H}$, the sampling frequency is calculated for the high-frequency range of the studied RS

$$
f_{S_{m}}=k_{B_{n}} \cdot f_{H} .
$$

4) From expression (40) is the sampling frequency for the $i$-th subband

$$
f_{S_{i}}=\frac{f_{S_{(i+1)}} \cdot \beta_{\max _{i}} \cdot M_{i}}{k_{f_{i}} \cdot \beta_{\max _{(i+1)}} \cdot M_{i+1}} .
$$

5) For each of the $m$ subsequences, the FFT is performed according to the obtained processing parameters and the spectral analysis of the studied broadband RS is performed.

Determine the effectiveness of the proposed method using the performance of digital RS processing. The performance of the method can be assessed by the number of multiplication operations during its implementation. The productivity ratio shows the gain in the number of required operations when applying the proposed method in relation to the method of direct implementation of FFT

$$
G=\frac{C_{F F T}}{C_{D S P}},
$$

where $C_{F F T}$ - the number of multiplication operations in the direct execution of the FFT of the entire array of RS samples; 
$C_{D S P}$ - the number of multiplication operations in the adaptive processing of subsequences formed from the array of samples of the studied RS.

Execution of the FFT algorithm requires $2 N \log _{2} N$ multiplication operations. The use of FFT for individual $m$ subsequences of volume $M$ requires $2 m \cdot M \log _{2} M$ multiplication operations. Hence the coefficient of productivity of the proposed method is equal to

$$
G=\frac{N}{m \cdot M} \log _{M} N
$$

In fig. 8 presents the dependence of the productivity factor on the volume of digital implementation of the studied RS for different lengths of the processed subsequences.

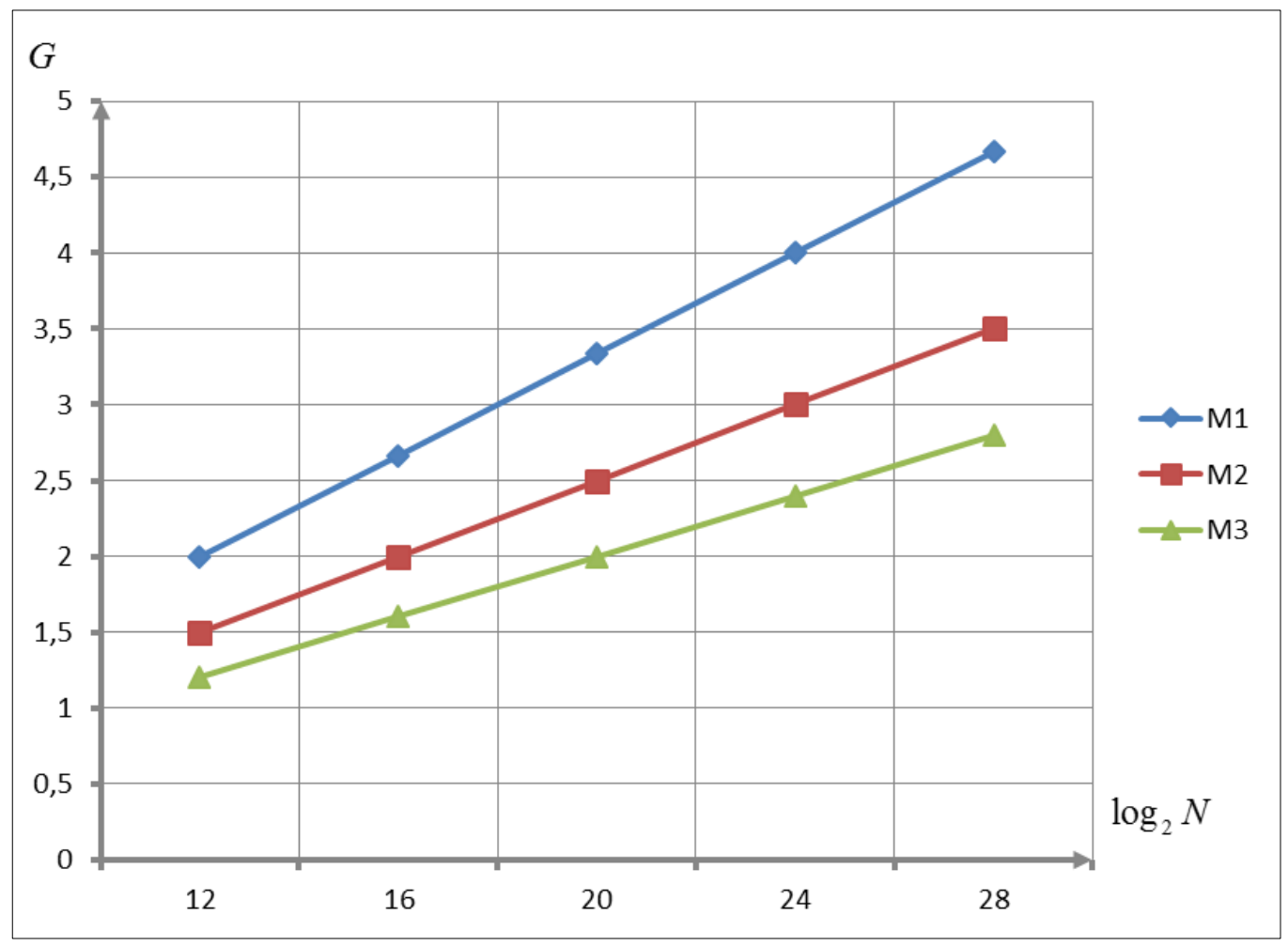

Fig. 8. Dependence of productivity ratios on volume implementation of RS for $M_{1}=64 ; M_{2}=256 ; M_{3}=1024$

As can be seen from the graphs, the performance of the proposed method improves with increasing sample size and is equal to $2,8 \div 4,6$ for the sample size of the studied RS $N=2^{28}$. With decreasing the length of the analyzed subsequence and increasing the number of processed subsequences, from $M_{3}=1024$ to $M_{1}=64$ productivity improves, namely equal to $2 \div 3,4$ for the sample size of the studied $\operatorname{RS} N=2^{20}$. 
Thus, the proposed method of spectral analysis makes it possible to significantly reduce the time to determine the frequency components of broadband RS. This method can be used in the means of primary processing of RS for spectral analysis of broadband RS in real time.

\section{CONCLUSIONS}

The paper proves that the limited dynamic range of analog-to-digital converters of RS and low productivity of digital signal processing processes lead to the fact that the characteristics of existing means of primary digital processing of RS do not reach their potential limits.

A method for expanding the dynamic range of the ADC of digital RS processing means by digital filtering of the output signals of the analogto-digital converter of the RS is proposed. Expressions for estimating the dynamic range of the ADC with filtering of output signals are obtained. Analysis of the effectiveness of the developed method showed that the dynamic range of ADCs with digital filtering of output signals in the operating frequency band by $6 \div 7 \mathrm{~dB}$ exceeds existing ADCs with analog filtering.

It is proposed to increase the productivity of digital means of memorization and reproduction of $\mathrm{RS}$ by reducing the computational complexity of DPRS procedures. A new method of memorizing and reproducing RS on the basis of multi-stage digital processing of samples of the studied RS is presented, which allows to reduce the time for finding the spectral and temporal components of the signal and to ensure the mode of operation of primary DPRS in real time.

It is shown that the productivity of the developed method exceeds the productivity of the classical method based on FFT by $1,4 \div 1,9$ times depending on the sample size of the analyzed RS. The presented method of spectral digital processing of RS creates conditions for operational analysis of RS spectra and leads to a significant reduction in the number of operations in digital filtering.

A new digital method of spectral analysis of broadband radio signals is presented, in which to increase productivity it is proposed to divide the implementation of the RS into a number of subsequences with their subsequent processing in the spectral region. It is proved that the productivity coefficient of the proposed method improves with increasing sample size and is equal to $2,8 \div 4,6$. It is indicated that this method can be used in real time in the means of primary processing of broadband RS. 


\section{SUMMARY}

The work is devoted to the development of methods of primary digital processing of radio signals (RS). It is proved that the real characteristics of the means of primary digital processing of radio signals (DPRS) do not reach their potential limits, due to the limited dynamic range of analog-todigital converters of RS and low productivity of DPRS processes.

The method of expanding the dynamic range of analog-to-digital converters (ADC) of primary DPRS due to digital filtering of ADC output signals is presented. The proposed method makes it possible to significantly expand the dynamic range of digital RS processing devices and ensure the operation of radio and telecommunications facilities with a wide class of signals.

A method of memorizing and reproducing RS is proposed, which makes it possible to increase the productivity of digital means of memorizing and reproducing $\mathrm{RS}$ by reducing the computational complexity of DPRS procedures. Methods for transferring RS from the time domain to the spectral domain on the basis of multi-stage digital processing of samples of the studied RS have been developed, which makes it possible to reduce the time for finding spectral and temporal signal components and ensure the mode of operation of primary DPRS.

A new digital method of spectral analysis of broadband RS is presented, which makes it possible to significantly reduce the time of determining the frequency components of broadband RS. This method can be used in the means of primary processing of RS for spectral analysis of broadband RS in real time.

\section{REFERENCES}

1. Рембовский А.М., Ашихмин А.В., Козьмин В.А. Радиомониторинг - задачи, методы средства. Москва, 2010. 624 с.

2. Бортник Г.Г., Кичак В.М. Методи та засоби обробки високочастотних сигналів : монографія. Вінниця : Універсум-Вінниця, 1998. 132 с.

3. Айфичер Э., Джервис У. Цифровая обработка сигналов: практический подход / пер. с англ. Москва, 2004. 992 с.

4. Кестер У. Проектирование систем цифровой и смешанной обработки сигналов / пер. с англ. Москва, 2010. 328 с.

5. Лайонс Р. Цифровая обработка сигналов / пер. с англ. Москва, 2006. $656 \mathrm{c}$.

6. Бортник Г.Г., Бортник С.Г., Кичак В.М. Методи та засоби аналого-цифрового перетворення високочастотних сигналів : монографія. Вінниця : ВНТУ, 2014. 128 с.

7. Бортник Г.Г., Бортник С.Г. Дослідження інтегральної нелінійності аналого-цифрового перетворювача у базисі дискретних 
функцій Фур'є. Вісник Вінницького політехнічного інституту. 2005. № 5. С. 117-119.

8. Бортник Г.Г., Васильківський М.В., Стальченко О.В. Пристрій аналого-цифрового перетворення високочастотних сигналів. Вимірювальна та обчислювальна техніка в технологічних процесах. 2013. № 2. C. 82-85.

9. Бортник Г.Г., Мінов М.Л., Стальченко О.В. Аналіз ефективності аналого-цифрового перетворення сигналів у радіотехнічних комплексах. Інформаційні технології та комп'ютерна інженерія. 2011. № 2. C. 12-15.

10. Смит С. Цифровая обработка сигналов. Практическое руководство для инженеров и научных работников. Москва, 2008. 720 с.

11. Ахмед Н., Рао К.Р. Ортогональные преобразования при обработке цифровых сигналов / пер. с англ. Москва, 1980. 248 с.

12. Бортник Г.Г. Швидкодіючий аналого-цифровий перетворювач підвищеної точності. Вісник Вінницького політехнічного інституту. 2002. № 5. C. 47-50.

13. Бортник Г.Г., Васильківський М.В., Стальченко О.В. Цифровий метод спектрального оцінювання випадкових сигналів. Вісник Вінницького політехнічного інституту. 2014. № 2. С. 108-114.

14. Радзиевский В.Г., Трифонов П.А. Обработка сверхширокополосных сигналов и помех. Москва, 2009. 288 с.

15. Афонский А.А., Дьяконов В.П. Цифровые анализаторы спектра, сигналов и логики. Москва, 2009. 248 с.

16. Ширман Я.Д. Радиоэлектронные системы: основы построения и теория. Москва, 2007. 512 с.

\section{Information about the authors: Bortnyk Gennadii Gryhorovych,} Candidate of Technical Sciences, Professor, Professor at the Department of Telecommunication Systems and Television Vinnytsia National Technical University 95, Khmelnytske shose str., Vinnytsya, 21021, Ukraine

Kyryliuk Serhii Alexandrovich, Postgraduate Student at the Department of Telecommunication Systems and Television

Vinnytsia National Technical University 95, Khmelnytske shose str., Vinnytsya, 21021, Ukraine 